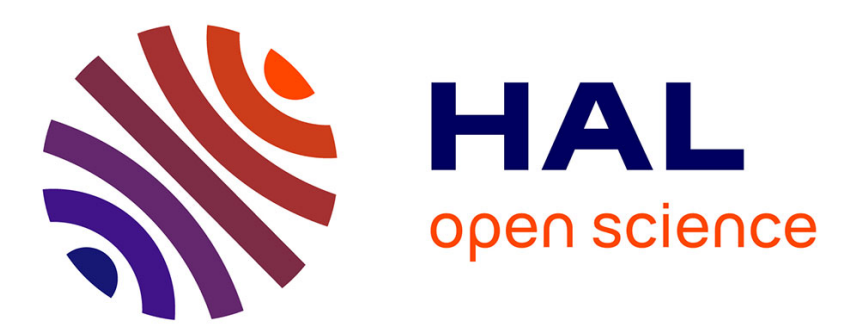

\title{
The intertemporal budget constraint and current account sustainability in Cyprus: Evidence and policy implications
}

Charalambos Pattichis

\section{- To cite this version:}

Charalambos Pattichis. The intertemporal budget constraint and current account sustainability in Cyprus: Evidence and policy implications. Applied Economics, 2010, 42 (04), pp.463-473. 10.1080/00036840802599875 . hal-00582209

\section{HAL Id: hal-00582209 \\ https://hal.science/hal-00582209}

Submitted on 1 Apr 2011

HAL is a multi-disciplinary open access archive for the deposit and dissemination of scientific research documents, whether they are published or not. The documents may come from teaching and research institutions in France or abroad, or from public or private research centers.
L'archive ouverte pluridisciplinaire HAL, est destinée au dépôt et à la diffusion de documents scientifiques de niveau recherche, publiés ou non, émanant des établissements d'enseignement et de recherche français ou étrangers, des laboratoires publics ou privés. 


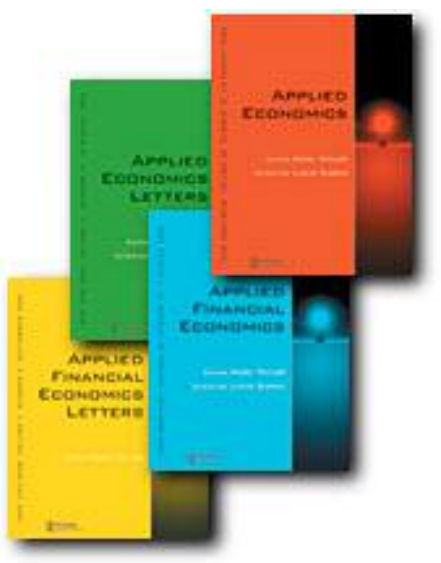

The intertemporal budget constraint and current account sustainability in Cyprus: Evidence and policy implications

\begin{tabular}{|r|l|}
\hline Journal: & Applied Economics \\
\hline Manuscript ID: & APE-06-0827.R1 \\
\hline Journal Selection: & Applied Economics \\
\hline $\begin{array}{r}\text { Date Submitted by the } \\
\text { Author: }\end{array}$ & $26-$ Jul-2008 \\
\hline Complete List of Authors: & Pattichis, Charalambos; Oxford Brookes University, Business School \\
\hline JEL Code: & $\begin{array}{l}\text { F32 - Current Account Adjustment/Short-Term Capital Movements } \\
<\text { International Finance < F - International Economics }\end{array}$ \\
\hline Keywords: & Current account sustainability, Cyprus \\
\hline
\end{tabular}

\section{s) ScholarONE" \\ Manuscript Central}




\title{
The intertemporal budget constraint and current account sustainability in Cyprus: Evidence and policy implications
}

\section{Charalambos Pattichis}

\author{
Business School \\ Oxford Brookes University \\ Wheatley Campus, Oxford OX33 1HX \\ UK \\ E-mail: pattichis15@yahoo.com
}

\begin{abstract}
Using the recently developed 'bounds' testing approach, this paper provides evidence that Cyprus is not in violation of its intertemporal budget constraint and its current account balance is 'strongly' sustainable in the long-run. A policy implication of these findings is that the loss of exchange rate policy following the adoption of the Euro in 2008 may not be a serious cost for Cyprus. On a methodological level, the results presented in this paper support theoretical models that employ an intertemporal approach to modeling the current account.
\end{abstract}

Keywords: Intertemporal budget constraint; current account sustainability; Cyprus.

JEL: F320, F410 


\section{Introduction}

The Republic of Cyprus, a full member of the European Union since May 2004, has decided to join the European Economic and Monetary Union (EMU) and adopt the euro as its currency. By giving up its own currency (the Cyprus pound) the country automatically loses the ability to devalue in order to tackle any possible future current account deficits. It is, therefore, important to ask whether Cyprus' current account balance is sustainable. If it is, then giving up its exchange rate policy may not be a serious cost of adopting the euro since the sustainability of the current account balance implies that this policy may not be required, ceteris paribus. However, if Cyprus' current account deficit is not sustainable, then the loss of exchange rate policy can impose serious economic costs on the country arising from the fact that Cyprus will need to use contractionary fiscal policy (which can harm economic growth) to tackle the growing external imbalances. The interested reader should consult De Grauwe (2003) for a comprehensive analysis of the costs and benefits of adopting a common currency. Note that within a currency union a country, by definition, loses its monetary policy and, thus, has to rely on fiscal policy for macroeconomic management.

Historically, Cyprus has not been using its exchange rate policy for competitive devaluations to improve the current account. Instead, the aim of exchange rate policy in Cyprus has been the maintenance of price and general macroeconomic stability through the linkage of the Cyprus pound exchange rate to some currency anchor (see Kyriacou (2002) for a detailed description of exchange rate policy in Cyprus). An import-weighted currency basket served as the currency anchor from 1973 to 1984, when it was replaced with a trade-weighted currency basket until 1992. From 1992 onwards, the Cyprus pound 
(CYP) was unilaterally pegged to the European Currency Unit (ECU) (and later the Euro) at a central parity rate of CYP1 $=1.7086 \mathrm{ECU}$ with fluctuation bands of $\pm 2.25 \%$. These bands were increased to $\pm 15 \%$ in January 2001 to enable the Central Bank of Cyprus to absorb any destabilizing capital movements that could arise from the process of capital account liberalization taking place in Cyprus (Kyriacou (2002)). In May 2005, the Cyprus pound joined the European Exchange Rate Mechanism II (ERM II) at the abovementioned central parity rate and fluctuation bands.

Figure 1 presents the time series of exports of goods and services of Cyprus and its imports of goods and services (plus net transfer payments and net interest payments). Both trade flows are in real terms. Figure 2 presents their difference (exports minus imports), i.e. the current account balance. Although real exports and imports seem to move together over time, since about 1999 the current account deficit has been increasing. The question, therefore, under investigation in this paper is whether Cyprus' current account deficit is sustainable.

To investigate this question, this paper follows the approach developed by Husted (1992) which tests for the existence of a long-run relationship between imports and exports. The rationale of such an approach is that if such a long-run relationship exists, the time series of imports and exports will never move too far apart from each other over time, implying that the current account balance is sustainable in the long-run. The next section presents the theoretical model and the testable hypotheses. Section 3 discusses the empirical results and the final section summarizes the conclusions and policy implications.

[TAKE IN FIGURES 1 AND 2 HERE] 


\section{Theoretical underpinnings and empirical formulation}

The approach of this paper follows closely Husted (1992). ${ }^{1}$ The approach tests for the existence of a long-run relationship between imports and exports. The rationale of such an approach is straightforward. If such a long-run relationship exists, the time series of imports and exports will tend to move closely together over time, i.e. they will not permanently diverge from one another, implying that the current account balance is sustainable. The theoretical model that lends support to the existence of such a long-run relationship is presented in Husted (1992) and is briefly summarized below.

Husted (1992) considers the case of a small open economy without a government sector that produces a single composite good. The representative consumer who lives in this economy is able to borrow and lend in international financial markets (at a given world interest rate) using one-period financial instruments. The agent's resources consist of endowments of output and redistributed profits and he uses them for consumption and savings to maximize intertemporal utility subject to these constraints. The current period budget constraint of this individual is given by:

$$
C_{0}=Y_{0}+B_{0}-I_{0}-\left(1+r_{0}\right) B_{-1}
$$

where $C_{0}, Y_{0}$, and $I_{0}$ are current period consumption, output, and investment, respectively; $r_{0}$ is the one-period world interest rate; $B_{0}$ is international borrowing, which could be

\footnotetext{
${ }^{1}$ Hakkio and Rush (1991) present a very similar model in the case of the government's intertemporal budget constraint. On the same topic see also, amongst others, Hamilton and Flavin (1986), Trehan and Walsh (1988), Quintos (1995) and Martin (2000).
} 
positive or negative; and $\left(1+r_{0}\right) B_{-1}$ is the initial debt, corresponding to the country's external debt.

The economy's intertemporal budget constraint (IBC) is obtained by combining the period-by-period budget constraints given in equation (1). Iterating (1) forward, Husted (1992) showed that the IBC can be expressed as:

$$
B_{0}=\sum_{t=1}^{\infty} \mu_{t} T A_{t}+\lim _{n \rightarrow \infty} \mu_{n} B_{n}
$$

where $T A_{t}=X_{t}-M_{t}\left(=Y_{t}-C_{t}-I_{t}\right)$ represents the trade balance in period $t$ (i.e. income minus absorption), $X_{t}$ equals exports, $M_{t}$ equals imports, $\lambda_{0}=1 /\left(1+r_{0}\right)$, and $\mu_{t}$ is the discount factor defined as the product of the first $t$ values of $\lambda$. If the last term in equation (2) is equal to zero the amount of borrowing (lending) in international markets is equal to the present value of all future trade surpluses (deficits). As Husted (1992) indicated, if this is not the case and $B_{0}$ is positive then the country is 'bubble-financing' its external debt, implying that the government will need to issue new debt. It is, therefore, critical to investigate whether the last term in equation (2) is equal to zero (Husted (1992) and Hakkio and Rush (1991)). To derive a testable model, Husted (1992) makes a number of assumptions (including that the world interest rate is stationary and that imports and exports are nonstationary (I(1)) series) and derives the following model:

$$
X_{t}=a+b M_{t}+u_{t}
$$


where $u_{t}$ is an error term. ${ }^{2}$ If $b$ equals one and $u_{t}$ is stationary then the economy satisfies its intertemporal budget constraint. In other words, if $M_{t}$ and $X_{t}$ are non-stationary, then the null hypothesis is that they are cointegrated and $b=1$. As Hakkio and Rush (1991) and Husted (1992) argued, the condition that exports and imports are cointegrated is necessary for the economy to satisfy its intertemporal budget constraint. However, the condition that $b=1$ is not. However, if $b$ is less than one, the economy will fail to satisfy its budget constraint if trade flows are expressed relative to output since this would be inconsistent with a finite external debt-to-output ratio, and hence with the sustainability of the current account balance (Hakkio and Rush (1991), Husted (1992)).

In the context of the government's IBC, Quintos (1995) has introduced 'strong' and 'weak' conditions for the sustainability of the budget deficit. Under the 'weak' condition she argued that cointegration between government revenues and expenditures is not a necessary but a sufficient condition for deficit sustainability, arguing that the necessary condition is that the debt grows more slowly than the borrowing rate. Following Quintos's work, Martin (2000) specifies that the government deficit is: (i) 'strongly' sustainable if and only if the I(1) processes of government revenues and expenditures are cointegrated and $b=1$; (ii) only 'weakly' sustainable if government revenues and

\footnotetext{
${ }^{2}$ Although equation (3) is specified as in Husted (1992) the empirical analysis in section 3 suggests that $X_{t}$ should be treated as a 'long run forcing' variable explaining $M_{t}$. Thus, the specification in section 3 becomes $M_{t}=a+b X_{t}+u_{t}$ and $b$ refers to the coefficient of $X_{t}$. This does not affect the two hypotheses that form the basis of the empirical analysis in this paper, which are: (a) Are $M_{t}$ and $X_{t}$ cointegrated, and (2) is $b=1$ ? For a similar approach see for example, Arize (2002) and Irandoust and Ericsson (2004).
} 
expenditures are cointegrated and $0<b<1$; and, (iii) the deficit is unsustainable if $b \leq 0$. Assuming, realistically, that these results carry over to the case of current account sustainability, the present paper focuses on a test of 'strong' sustainability of Cyprus' current account.

In this paper, following Husted (1992) (see also, amongst others, Baharumshah, Lau and Fountas (2003)), $X_{t}$ represents exports of goods and services, and $M_{t}$ measures imports of goods and services plus net transfer payments and net interest payments. As Hakkio and Rush (1991) and Husted (1992) have noted there are a number of ways to measure trade flows: in nominal terms, in real terms, and as a proportion of nominal or real Gross Domestic Product (GDP). Hakkio and Rush (1991) further argued that since in the theoretical model the interest rate is assumed stationary, nominal interest rates are ruled out since they are usually non-stationary. Thus, following Hakkio and Rush (1991) this paper focuses on real trade flows. Furthermore, since $b$ being less than one implies that the economy will fail to satisfy its budget constraint if trade flows are expressed relative to output, the paper also analyzes the case of real trade flows as a proportion of real GDP (Hakkio and Rush (1991)).

Several studies have empirically employed the model, see for example, Husted (1992), Bahmani-Oskooee and Rhee (1997), Fountas and Wu (1999), Apergis, Katrakilidis, and Tabakis (2000), Wu, Chen and Lee (2001), Arize (2002), Baharumshah, Lau and Fountas (2003), and Irandoust and Ericsson (2004). To the best of our knowledge, the only study that has analyzed the case of Cyprus is Arize (2002). However, Arize (2002) focused on imports and exports of goods only (i.e. on the trade balance) while the present paper focuses on the current account. Furthermore, the analysis presented here is conducted in 
real terms (as opposed to Arize (2002) who used nominal values) and employs different (and more recent) statistical techniques to bear on the issue.

\section{Empirical results}

\section{Variable specification and data sources}

All data used in this paper were taken from the International Financial Statistics (IFS) CD-ROM of the International Monetary Fund. The study uses annual data from 19762004 since quarterly data were not available in IFS for most of the sample period. (Since Cyprus was divided in 1974 following the Turkish invasion, our sample starts in 1976. The focus is the government-controlled (Greek) part of Cyprus.) As indicated in the previous section our export series represents exports of goods and services, and our imports series measures imports of goods and services plus net transfer payments and net interest payments. These series were constructed using data from the Balance of Payments section of the IFS. All dollar values were transformed into Cyprus pounds using the bilateral exchange rate (IFS code $r h$ ). All variables (except the current account balance) were transformed into natural logarithms prior to the empirical analysis. The definition of the variables used in the empirical analysis is given below.

Real exports (LRX): These are exports of goods and services deflated by the GDP deflator (base year=2000; IFS code 99bip). No data are available for an export price index. The use of the GDP deflator is guided by the fact that it represents domestically produced goods (some of which are exported). 
Real imports (LRM): These are imports of goods and services plus net transfer payments and net interest payments deflated by the Consumer Price Index (CPI) (base year=2000; IFS code 64). As in the case of exports, no data exist for a price index of imports. We have used the CPI as a deflator since it also includes the prices of imported goods. It should be noted that the CPI and GDP deflator series are very similar to one another. Thus, in deriving measures of real imports and real exports, it makes no real difference if one deflates the nominal trade figures by the CPI or the GDP deflator.

Current Account balance (RCA): This is defined as real exports minus real imports.

Real exports as a proportion of real GDP (LRXGDP): These are real exports (as defined above) expressed as a proportion of real GDP. The latter is nominal GDP (IFS code 99b) deflated by the GDP deflator.

Real imports as a proportion of real GDP (LRMGDP): These are real imports (as defined above) expressed as a proportion of real GDP.

\section{Unit root analysis}

All variables used in the empirical analysis have been tested for unit roots using the Augmented Dickey-Fuller (ADF) test (see Dickey and Fuller $(1979,1981))$ and the DFGLS test proposed by Elliott, Rothenberg and Stock (1996).

The ADF test results (with and without a trend included in the model) are presented in Table 1. The appropriate lag length of the autoregression was chosen based on the Akaike Information Criterion using a maximum lag order of two which was dictated by the small sample size. (The use of the Schwarz Information Criterion (SIC) yielded similar conclusions about the time series properties of the variables.) As in the case of the ADF 
tests, the DF-GLS test was also done with and without a trend included in the model. ${ }^{3}$ The DF-GLS results are presented in Table 2. The order of augmentation of the DF-GLS tests was based on two information criteria: the Modified Akaike Information Criterion (MAIC) (see Ng and Perron (2001)) and the Schwarz Information Criterion (SIC) using a maximum lag order of two. In those cases where the MAIC and the SIC selected different lag lengths with different conclusions about the time series properties of the variables, the paper reports results for both. In all such cases the SIC selected lag 1 and the MAIC selected lag 2. Table 2 also reports two critical values: the $5 \%$ critical values based on the response surface analysis of Cheung and Lai (1995) and the 5\% interpolated critical values based on Elliott et al (1996).

\section{[TAKE IN TABLES 1 AND 2 HERE]}

The ADF test results reported in Table 1 suggest that the current account balance (RCA) is stationary. However, the DF-GLS test results are not so clear. The latter suggest that if inference is based on the model with lag 1 (selected by SIC) then RCA is indeed an I(0) variable regardless of whether or not a trend is included in the model. However, if inference is based on the model with lag 2 (selected by MAIC) then RCA appears to be an I(1) variable. STATA 10 also reports another information criterion: the $\mathrm{Ng}$ and Perron (1995) sequential-t method. Based on this information criterion (not reported in Table 2) the analysis suggests that RCA is an $\mathrm{I}(0)$ variable. Thus, overall the results suggest that

${ }^{3}$ The econometric analysis in this paper was conducted using MICROFIT 4.0 (Pesaran and Pesaran (1997)) except the Phillips-Perron test and the DF-GLS test which were both done using STATA 10 (StataCorp (2007)). I would like to thank Mona Kanaan for her assistance with STATA. 
RCA is a stationary variable. This result carries the important implication that Cyprus' current account deficit is sustainable.

Turning now to variables LRXGDP and LRMGDP, the ADF test results suggest that these variables are $\mathrm{I}(0)$ processes. This conclusion is also supported by the DF-GLS test results which clearly suggest that LRXGDP is an I(0) variable. The results also suggest that LRMGDP is an I(0) variable if the model with lag 1 is used (selected by SIC) regardless of whether or not a trend is included in the model. However, in the No Trend case the MAIC selects lag 2 and based on this the analysis just fails to reject the unit root null if the Cheung and Lai (1995) critical values are used. The unit root null, however, is rejected if the Elliott et al (1996) critical values are used. The conclusion that LRMGDP is an $\mathrm{I}(0)$ variable is also supported if inference is based on the lag length chosen by the $\mathrm{Ng}$ and Perron (1995) sequential-t method. Thus, we proceed on the conclusion that both LRXGDP and LRMGDP are I(0) variables.

Based on the ADF unit root results, LRX is clearly an I(1) variable, whereas LRM is I(1) if no trend is included in the $\mathrm{ADF}$ regression but $\mathrm{I}(0)$ if such a trend is included. The latter result is somewhat surprising given that the plots of LRM and LRX indicate similar behavior over time. In fact, the ADF $t_{\tau}$ statistic of -4.42 is based on the estimation period 1979-2004 which is used by the econometric software package following our specification of a maximum lag order of two. If the same ADF regression is estimated over the period 1978-2004 (i.e. one more observation) the ADF $t_{\tau}$ statistic is -3.68 . This substantial reduction in the magnitude of the statistic may suggest considerable sample dependence. In other words, with a bigger sample, the finding might have been that LRM is $\mathrm{I}(1)$. 
To investigate this further we have also tested LRM and LRX for unit root behavior using the Phillips-Perron test and the DF-GLS test. The Phillips-Perron tests (see Phillips and Perron (1988)) have failed to significantly clarify the situation (results not presented but available on request). The Phillips-Perron $\mathrm{Z}(t)$ statistic confirms that LRX is an I(1) variable. This conclusion is robust to different truncation lag orders for the Newey-West adjustment of the variances and regardless of whether a trend is included or not in the model. However, as in the case of the ADF test, the Phillips-Perron Z(t) results suggest that (at the 5\% significance level) LRM is I(1) if no trend is included in the model but $\mathrm{I}(0)$ if a trend is included. However, at the $1 \%$ level the unit root null for LRM cannot be rejected even in the case when a trend is included in the model.

Turning now to the results based on the DF-GLS test the picture becomes much clearer. It is clear from Table 2 that regardless of which critical values one uses both LRX and LRM appear to be I(1) variables at the 5\% level under both the trend and no-trend cases. Thus, we proceed to the cointegration analysis based on this conclusion.

\section{The long-run relationship between LRM and LRX}

The long-run relationship between LRM and LRX (both of which have been found to be I(1) variables based on the DF-GLS test) is investigated using the 'bounds' test. The 'bounds' test for the existence of a long-run level relationship between a dependent variable and a set of regressors advanced by Pesaran, Shin and Smith (2001) (see also Pesaran and Pesaran (1997)) is based on the F-statistic and is used to test the joint significance of the lagged levels of the included variables in an unrestricted error correction model (UECM). Pesaran, Shin and Smith (2001) show that the asymptotic 
distribution of this F-statistic is non-standard, under the null hypothesis that there exists no long-run relationship between the variables, irrespective of whether the underlying regressors are $\mathrm{I}(0)$ or $\mathrm{I}(1)$.

In the case of two variables (LRM and LRX) the UECM takes the following form:

$$
\Delta L R M_{t}=\alpha_{0}+\sum_{i=1}^{n} \beta_{i} \Delta L R M_{t-i}+\sum_{i=0}^{n} \gamma_{i} \Delta L R X_{t-i}+\delta L R M_{t-1}+\varepsilon L R X_{t-1}+u_{t}
$$

where $\triangle L R M$ and $\triangle L R X$ are the first differences of the logarithms of LRM and LRX respectively, and $u_{t}$ is an error term. As Hendry et al (1984) noted this UECM is a simple reparameterisation of a general autoregressive distributed lag (ARDL) model.

The null hypothesis of no long-run level relationship (i.e. no cointegration) is tested by estimating the UECM and testing the joint significance of the lagged levels in equation (4), i.e. $H_{0}: \delta=\varepsilon=0$. Pesaran et al (2001) have tabulated the appropriate critical values for different number of regressors and various specifications of the deterministic components (intercept and trend and whether these should be restricted or unrestricted). They also provide two sets of asymptotic critical values (lower and upper critical bounds; hence the name for the test) for the two extreme cases: one that assumes that all regressors are $\mathrm{I}(0)$ and the other that all regressors are $\mathrm{I}(1)$. If the computed F-statistic exceeds the upper critical bound then the hypothesis of no long-run relationship is rejected, and such inference is made without knowing the order of integration of the regressors. In this way, the pre-testing problems and uncertainty involved in unit root tests are avoided. However, if the computed F-statistic is lower than the lower critical bound then the null hypothesis cannot be rejected. Finally, if the computed statistic falls 
inside the critical bounds, inference is inconclusive and one needs to establish the order of integration of the underlying regressors before conclusive inference can be made.

The 'bounds' test is based on the assumption that the residuals in equation (4) are serially uncorrelated. It is, therefore, important that the lag order $n$ be selected appropriately. It is also important to decide the appropriate specification of the deterministic components to be included in the model. To decide on the lag order, models were estimated for $n=1,2,3$ and the choice of the appropriate model was based on the AIC and SIC criteria. Both information criteria suggest that the appropriate model is $n=1$. The results of this model are presented in Table 3. It is clear that the model passes all the usual diagnostic tests including the cumulative sum (CUSUM) and cumulative sum of squares of recursive residuals (CUSUMSQ) tests for structural stability (not reported but available on request) (see Brown, Durbin, and Evans (1975)). An inspection of the residuals suggests that there are no outliers. Only in one case the residual was slightly greater than two times the standard error of the regression and no residual was greater than three times the standard error of the regression. Thus, no dummy variables have been used.

\section{[TAKE IN TABLE 3 HERE]}

Equation (4) was also estimated with a time trend included in the model. The AIC and SIC indicated that, in this case as well, the appropriate lag order is $n=1$. The information criteria suggested that the model without a trend is slightly better. Since the results of the two models are very similar, the model with a deterministic trend is not reported here. The model passes all the usual diagnostic tests (see Notes to Table 3 for details on these tests). The results suggest that the time trend is highly statistically insignificant. 
The 'bounds' test for the existence of a long run relationship was conducted based on these two estimated models, using three different specifications for the deterministic components. These three specifications were: (a) unrestricted intercept and no trend (Case III in Pesaran et al (2001)); (b) unrestricted intercept and restricted trend (Case IV in Pesaran et al (2001)); and, (c) unrestricted intercept and unrestricted trend (Case V in Pesaran et al (2001)). The results are presented in Table 4.

\section{[TAKE IN TABLE 4 HERE]}

Table 4 reports two sets of critical values: (a) those reported in Pesaran et al (2001) which relate to large samples; and (b) those reported in Narayan (2005) which relate to small samples. It is clear from Table 4 that in all cases, the computed F statistic is greater than the upper critical bounds, suggesting that the null hypothesis cannot be accepted. Thus, the 'bounds' test results clearly suggest the existence of a long-run level relationship between LRM and LRX.

Unrestricted error correction models of the form given in equation (4) (with and without a deterministic trend) were also estimated with $\triangle \mathrm{LRX}$ as the dependent variable (results not reported but available on request). The 'bounds' tests in this case suggested the absence of a long-run relationship between the variables since the estimated F-statistics fell below the lower critical values (implying that cointegration is only present when LRM is the dependent variable (Narayan and Narayan (2005)). This suggests that LRX is a 'long-run forcing' variable explaining LRM (Pesaran and Pesaran (1997)). Thus, in the remaining of the paper we will treat LRM as the dependent variable with long-run exports assumed given. This is not unrealistic for a small (resource-scarce) economy such as Cyprus, since 
an increase in exports will require higher imports of, for example, raw materials. For a similar approach see for example, Arize (2002) and Irandoust and Ericsson (2004).

Having established the existence of a long-run relationship, the paper proceeds to estimate the long-run coefficients using the ARDL approach advocated by Pesaran and Shin (1999) (see also Pesaran and Pesaran (1997)). Pesaran and Shin (1999) have shown that after appropriate augmentation of the order of the ARDL model, the ARDL-based estimators of the long-run coefficients are super-consistent and valid inferences can be made using standard normal asymptotic theory. They have also shown that appropriate choice of the order of the ARDL model tackles any endogenous regressor problems and that their approach is applicable irrespective of whether the regressors are $\mathrm{I}(0)$, I(1) or mutually cointegrated.

In the case of two variables in levels (LRM and LRX) the ARDL model takes the following form:

$$
L R M_{t}=\alpha+\sum_{i=1}^{p} \beta_{i} L R M_{t-i}+\sum_{i=0}^{p} \gamma_{i} L R X_{t-i}+\varepsilon_{t}
$$

where $\varepsilon_{t}$ is an error term. The appropriate model is selected on the basis of information criteria and the long-run coefficient of $\operatorname{LRX}(b)$ is derived as:

$$
b=\frac{\sum_{i} \gamma_{i}}{\left(1-\sum_{i} \beta_{i}\right)} .
$$

Using a maximum lag order of $p=2$, the AIC selected an ARDL $(2,2)$ model. The model (results not reported but available on request) passes all the usual diagnostic tests at the $5 \%$ level (see Notes of Table 3 for information on these tests). The long-run relationship 
between LRM and LRX derived from the ARDL $(2,2)$ model is given as $(t$-ratios in brackets):

$$
\mathrm{LRM}_{\mathrm{t}}=0.159+0.988 \mathrm{LRX}_{\mathrm{t}}
$$

Thus, the coefficient of LRX is statistically significant and almost equal to 1 in magnitude. ${ }^{4} \mathrm{~A}$ Wald test of the hypothesis that $b=1$ is accepted by the data $\left(\chi^{2}(1)=0.245\right.$ [p-value $=0.620])$. These results suggest that Cyprus is not in violation of its intertemporal budget constraint. ${ }^{5}$

Furthermore, the results suggest that the coefficient of the lagged error correction term (1.04; $t$-ratio: -4.92$)$ in the error correction representation of the model is correctly signed and statistically significant, thus confirming the conclusion that a long run relationship exists between the variables (see Engle and Granger (1987)). Its magnitude suggests high

\footnotetext{
${ }^{4}$ It should be noted that an almost identical long run model is derived if the order of the ARDL model is selected on the basis of the SIC. Furthermore, an identical long-run coefficient of LRX is derived using the results of the UECM presented in Table 3. Based on equation (4) the long-run coefficient in this case is calculated as: $-(\varepsilon / \delta)$. This is not surprising since, as argued before, the UECM is a simple reparameterisation of an ARDL model.

${ }^{5}$ The Johansen procedure has also been used as a robustness check of the results. The Johansen results confirm that LRX and LRM are cointegrated and the resulting cointegrating vector is very similar to the one reported in the main body of the article. Furthermore, the hypothesis that $b=1$ was accepted by the data.
} 
speed of convergence to equilibrium, which takes about one year. In addition, this error correction model passes all the usual diagnostic tests.

\section{The long-run relationship between LRMGDP and LRXGDP}

The unit root test results presented in Tables 1 and 2 suggest that both LRXGDP and LRMGDP are I(0) variables. The stationarity of these variables implies that the 'spurious' regression problem identified by Granger and Newbold (1974) is not applicable here. However, it should be noted that in the theoretical framework used to derive the testable model, Husted (1992) assumes that exports and imports are I(1) series, and a country satisfies its IBC if these nonstationary series are cointegrated. Since both our variables are $\mathrm{I}(0)$, the concept of cointegration is not applicable and the relevance of the theoretical model questionable. Thus, the approach here is to simply estimate the long-run relationship and test whether $b$ is statistically significant and equal to one (and ensure that the residuals of our model have the desirable properties). Therefore, the analysis in this section should be treated with caution.

To derive the long-run relationship between the variables, we estimated a simple static regression by ordinary least squares of the form:

$$
\operatorname{LRMGDP}_{\mathrm{t}}=a+b \operatorname{LRXGDP}_{\mathrm{t}}+u_{t}
$$

where $u_{t}$ is an error term. The estimated equation is given as ( $t$-ratios in brackets):

$$
\begin{aligned}
\text { LRMGDP }_{\mathrm{t}}= & 0.016+0.931 \mathrm{LRXGDP}_{\mathrm{t}} \\
& (0.1) \quad(4.07)
\end{aligned}
$$

(A trend was also included in the model but since it was statistically insignificant it was subsequently dropped from the specification.) The static model passes all the usual diagnostic tests at the $5 \%$ level, except the test for Normality (results not reported but 
available on request). The model also marginally fails the CUSUM test for structural stability at the $5 \%$ level. An ADF unit root test of the residuals of the static equation confirms that they are stationary (estimated $\mathrm{ADF}$ (of lag 1) statistic=-4.7; critical value: 3.58). A Wald test of the hypothesis that $b=1$ was accepted by the data $\left(\chi^{2}(1)=0.09\right.$ [pvalue $=0.763])$. These results further suggest that Cyprus' current account balance is sustainable.

To further check the robustness of the results, we have estimated an ARDL(2,2) model for LRMGDP (lag order selected by the AIC using a maximum lag order of two). This model passes all the usual diagnostic tests (including the CUSUM and CUSUMSQ tests for structural stability) and the results are presented in Table 5.

[TAKE IN TABLE 5 HERE]

The long-run relationship derived from the ARDL model is given as ( $t$-ratios in brackets):

$$
\begin{aligned}
\text { LRMGDP }_{\mathrm{t}}= & 0.165+1.138 \text { LRXGDP }_{\mathrm{t}} \\
(0.9) & (4.27)
\end{aligned}
$$

A Wald test of the hypothesis that $b=1$ was accepted by the data $\left(\chi^{2}(1)=0.27\right.$ [pvalue $=0.604])$. Thus, these results further support the conclusions of the previous models. These conclusions and their implications are summarized in the next section. 


\section{Conclusions and policy implications}

Cyprus has decided to join the European monetary union and adopt the euro as its currency. One of the costs of joining a monetary union is the loss of exchange rate policy (the ability to devalue in order to tackle current account deficits). Whether the loss of this policy is a serious cost of joining the Eurozone depends to a large extent on whether the current account balance of Cyprus is sustainable. If this is the case, and given that Cyprus has not been following a policy of competitive devaluations to improve its current account over the period under consideration, it implies that the loss of the exchange rate policy may not be a serious cost of adopting the Euro since the country may not require the use of this policy, ceteris paribus.

To investigate this question, this paper used the approach developed by Husted (1992) which tests for the existence of a long-run relationship between imports and exports. If such a long-run relationship exists, the time series of imports and exports will never move too far apart from each other over time, implying that the current account balance is sustainable in the long-run. This paper has studied the sustainability of Cyprus' current account in three ways: (a) By testing for stationarity of the current account balance; (b) by testing for the existence of a long-run relationship between real imports and real exports; and (c) by investigating the long-run relationship between real imports and real exports, both expressed as a proportion of real GDP.

The results presented in this paper suggest that the current account balance is stationary and that a valid long-run relationship exists between real imports and real exports of goods and services. These results point to the conclusion that Cyprus is not in violation of its intertemporal budget constraint and the current account balance is sustainable in the 
long-run. Furthermore, the results suggest that the coefficient of exports is equal to one, implying that the current account balance is 'strongly' sustainable.

A policy implication of these findings is that the loss of exchange rate policy following the adoption of the Euro may not be a serious cost for Cyprus. This conclusion derives from the fact that even though Cyprus has not been using competitive devaluation policies over the period under investigation, the current account balance was sustainable. Thus, ceteris paribus, Cyprus may not require the use of this policy and, therefore, its loss may not constitute a serious cost of adopting the Euro.

However, it may be argued that the sustainability of the current account was the result of proper macroeconomic policies that ensured that any short-run imbalances were corrected and the economy was guided towards the long-run equilibrium. As we have already mentioned, Cyprus has not been following a policy of competitive devaluations over the period under investigation. However, this does not mean that the exchange rate policy followed by Cyprus had no positive effect on the current account. The policy of pegging the Cyprus pound exchange rate to some currency anchor has helped in keeping inflation low and stable and this, in turn, had a positive impact on the international competitiveness of the economy. Furthermore, the finding of current account sustainability may have been the result of proper fiscal and monetary policies. By becoming a member of EMU, Cyprus loses its monetary policy and exchange rate policy and constraints are imposed on its fiscal policy. Thus, whether Cyprus will continue to satisfy its IBC remains to be seen.

The main point that can be made at this stage is that if the finding had been that the current account was not sustainable, then the loss of exchange rate policy would have 
been a serious cost of adopting the euro. However, the results of this paper suggest that Cyprus is not in violation of its IBC and its current account balance is sustainable in the long-run. Thus, it may be argued that the loss of a policy instrument in such a case may not be a serious cost of joining EMU. On a methodological level, the results presented in this paper support theoretical models that use an intertemporal approach to the current account.

\section{ACKNOWLEDGEMENTS}

I would like to thank an anonymous referee of this journal for useful and constructive comments on an earlier draft. I am, of course, solely responsible for any remaining errors. 


\section{REFERENCES}

Apergis, N., Katrakilidis, K.P., and Tabakis, N.M. (2000), "Current account sustainability: the case of Greece", Applied Economics Letters 7, 599-603.

Arize, A.C. (2002), "Imports and exports in 50 countries: Tests of cointegration and structural breaks", International Review of Economics and Finance 11, 101-115.

Baharumshah, A.Z., Lau, E., and Fountas, S. (2003), "On the sustainability of current account deficits: evidence from four ASEAN countries", Journal of Asian Economics 14, 465-487.

Bahmani-Oskooee, M. and Rhee, H.J. (1997), “Are imports and exports of Korea cointegrated? International Economic Journal 11, 109-114.

Bera, A.K. and C.M. Jarque (1981), "An efficient large sample test for normality of observations and regression residuals", Australian National University Working Papers in Econometrics 40, Canberra.

Brown, R.L., Durbin, J. and Evans, J.M. (1975) “Techniques for testing the constancy of regression relations over time", Journal of the Royal Statistical Society B 37:149192.

Cheung, Y.W. and Lai, K.S. (1995), "Lag order and critical values of a modified DickeyFuller test”, Oxford Bulletin of Economics and Statistics 57, 411-419.

De Grauwe, P. (2003). The Economics of Monetary Union, $5^{\text {th }}$ Edition, Oxford University Press, Oxford and New York.

Dickey, D.A. and Fuller, W.A. (1979), "Distribution of the estimators for autoregressive time series with a unit root", Journal of the American Statistical Association 74, 427-431. 
Dickey, D.A. and Fuller, W.A. (1981), "Likelihood ratio statistics for autoregressive time series with a unit root", Econometrica 49, 1057-1072.

Elliott, G., Rothenberg, T.J. and Stock, J.H. (1996), "Efficient tests for an autoregressive unit root", Econometrica 64, 813-836.

Engle, R. F. (1982), “Autoregressive conditional heteroskedasticity with estimates of the variance of UK inflation", Econometrica, 50, 987-1008.

Engle, R.F. and Granger, C.W.J. (1987), "Co-integration and error correction: Representation, estimation and testing", Econometrica, 55, 251-276.

Fountas, S. and Wu, J.L. (1999), “Are the US current account deficits really sustainable? International Economic Journal 13, 51-58.

Godfrey, L.G. (1978a), “Testing against general autoregressive and moving average error models when the regressors include lagged dependent variables", Econometrica, 46, 1293-1301.

Godfrey, L.G. (1978b), "Testing for higher order serial correlation in regression equations when the regressors include lagged dependent variables", Econometrica, 46, 1303-1310.

Granger, C.W.J., and Newbold, P. (1974), "Spurious regressions in econometrics", Journal of Econometrics 2, 111-120.

Hakkio, C. and Rush, M. (1991), "Is the budget deficit too large?, Economic Inquiry 29, $429-445$.

Hamilton, J.D. and Flavin, M.A. (1986), “On the limitations of government borrowing: a framework for empirical testing”, American Economic Review 76, 808-819.

Harvey, A. C. (1981), The econometric analysis of time series, London: Phillip Allan. 
Hendry, D.F., Pagan, A., and Sargan, J.D. (1984) "Dynamic specification”, in Handbook of Econometrics II, (Eds) Z. Griliches and M. Intrilligator, North Holland, Amsterdam, 1023-1100.

Husted, S. (1992), “The emerging US current account deficit in the 1980s: a cointegration analysis", The Review of Economics and Statistics 74, 159-166.

Irandoust, M. and Ericsson, J. (2004), “Are imports and exports cointegrated? An international comparison", Metroeconomica 55, 49-64.

Kyriacou, G. (2002), "The current framework of exchange rate policy in Cyprus and recent developments", Cyprus Journal of European Studies 1(2).

Martin, G.M. (2000), "US deficit sustainability: A new approach based on multiple endogenous breaks", Journal of Applied Econometrics 15, 83-105.

Narayan, P.K. (2005), “The saving and investment nexus for China: evidence from cointegration tests", Applied Economics 37, 1979-1990.

Narayan, P.K. and Narayan, S. (2005), "Estimating income and price elasticities of imports for Fiji in a cointegration framework", Economic Modelling 22, 423-438.

Ng, S. and Perron, P. (1995), "Unit root tests in ARMA models with data-dependent methods for the selection of the truncation lag", Journal of the American Statistical Association 90, 268-281.

Ng, S. and Perron, P. (2001), "Lag length selection and the construction of unit root tests with good size and power", Econometrica 69, 1519-1554.

Pesaran, M. H. and Pesaran, B. (1997), Microfit 4.0: Interactive Econometric Analysis, Oxford University Press, Oxford. 
Pesaran, M.H. and Shin, Y. (1999), “An autoregressive distributed lag modelling approach to cointegration analysis", in S Strom (ed.), Econometrics and Economic Theory in the 20th Century: The Ragnar Frisch Centennial Symposium, chapter 11, Cambridge University Press, Cambridge.

Pesaran, M.H., Shin, Y., and Smith, R.J. (2001), "Bounds testing approaches to the analysis of level relationships", Journal of Applied Econometrics 16, 289-326.

Phillips, P.C.B. and Perron, P. (1988), “Testing for a unit root in time series regression", Biometrika, 75, 335-346.

Quintos, C.E. (1995), "Sustainability of the deficit process with structural shifts", Journal of Business and Economic Statistics 13, 409-417.

Ramsey, J. B. (1969), “Tests for specification errors in classical linear least squares regression analysis", Journal of the Royal Statistical Society B, 31, 350-371.

StataCorp. (2007), Stata Statistical Software: Release 10, College Station, TX: StataCorp LP.

Trehan, B. and Walsh, C.E. (1988), "Common trends, the government's budget constraint, and revenue smoothing", Journal of Economic Dynamics and Control $12,425-444$.

White, H. (1980), “A heteroskedasticity-consistent covariance matrix estimator and a direct test for heteroskedasticity", Econometrica, 48, 817-838.

Wu, J-L., Chen, S-L., and Lee, H-Y. (2001), “Are current account deficits sustainable? Evidence from panel cointegration”, Economics Letters 72, 219-224. 


\section{TABLES AND FIGURES}

Table 1: Augmented Dickey-Fuller unit root tests

\begin{tabular}{lcccc}
\hline Variable & \multicolumn{3}{c}{$\mathrm{L}$} & \multicolumn{2}{c}{$\Delta \mathrm{L}$} \\
\hline & $t_{\mu}$ & $t_{\tau}$ & $t_{\mu}$ & $t_{\tau}$ \\
\hline RCA & $-3.51(1)$ & $-4.37(1)$ & $-5.01(2)$ & $-4.95(2)$ \\
LRX & $-2.13(0)$ & $-2.48(0)$ & $-5(0)$ & $-5.27(0)$ \\
LRM & $-1.45(0)$ & $-4.42(1)$ & $-4.68(2)$ & $-4.82(2)$ \\
LRXGDP & $-4.07(2)$ & $-3.85(2)$ & $-4.73(0)$ & $-4.79(0)$ \\
LRMGDP & $-4.83(1)$ & $-4.72(1)$ & $-4.75(2)$ & $-4.64(2)$ \\
\hline
\end{tabular}

Notes (Table 1): $\mathrm{L}$ and $\Delta \mathrm{L}$ denote the level and first difference of the series, respectively. $t_{\mu}$ is the ADF $t$-ratio with a constant but no trend and $t_{\tau}$ is the ADF $t$-ratio with a constant and a trend included in the ADF regression. The order of augmentation of the ADF tests (given in brackets) was selected by the Akaike Information Criterion using a maximum order of two. The use of a maximum order of three yields similar conclusions. The 5\% critical values are -2.98 for the $t_{\mu}$ test and -3.6 for the $t_{\tau}$ test. 
Table 2: Elliott et al (1996) DF-GLS test statistics

\begin{tabular}{lccccccc}
\hline Model & RCA & LRX & LRM & LRXGDP & LRMGDP & CL-5\% & ERS-5\% \\
\hline Trend & $-4.22(1)$ & $-2.66(1)$ & $-3.13(1)$ & $-4.11(1)$ & $-4.17(1)$ & -3.37 & -3.19 \\
\multirow{2}{*}{ No Trend } & $-2.84(2)$ & & & & & -3.29 & \\
& $-2.78(1)$ & $-0.19(1)$ & $0.09(1)$ & $-4.13(1)$ & $-3.11(1)$ & -2.44 & -1.95 \\
& $-1.43(2)$ & & & & $-2.32(2)$ & -2.39 & \\
\hline
\end{tabular}

Notes (Table 2): The column entitled Model indicates whether or not a trend is included in the model. The order of augmentation of the DF-GLS tests (given in brackets) was based on two information criteria reported by STATA 10: the Modified Akaike Information Criterion (MAIC) (see Ng and Perron (2001)) and the Schwarz Information Criterion (SIC) using a maximum lag order of two. In those cases where the MAIC and the SIC selected different lag lengths with different conclusions about the time series properties of the variables, the table reports the results for both. In all such cases the SIC selected lag 1 and the MAIC selected lag 2. The table reports two critical values given by STATA 10: CL-5\% reports the 5\% critical values based on the response surface analysis of Cheung and Lai (1995) and ERS-5\% reports the 5\% interpolated critical values based on Elliott et al (1996). The CL-5\% column reports two critical values: the first number applies to models with lag 1 and the second number to models with lag 2. The ERS-5\% critical values reported by STATA are the same for both models. 
Table 3: Results of the unrestricted error correction model for $\Delta \mathrm{LRM}$

\begin{tabular}{lcc}
\hline $\begin{array}{l}\text { Dependent variable is } \Delta \text { LRM } \\
\text { OLS estimation from 1978-2004 }\end{array}$ & & \\
\hline Regressor & Coefficient & $t$-statistic \\
\hline Constant & 0.165 & 0.87 \\
$\Delta$ LRM $(-1)$ & 0.402 & 2.5 \\
$\Delta$ LRX & 1.046 & 7.19 \\
$\Delta$ LRX $(-1)$ & -0.485 & -2.05 \\
LRM $(-1)$ & -1.039 & -4.92 \\
LRX $(-1)$ & 1.027 & 4.89 \\
\hline & DIAGNOSTIC TESTS & \\
\hline Adjusted R & 0.79 \\
F-statistic & $\mathrm{F}(5,21)=[0.000]$ \\
SER & 0.052 \\
Durbin's h-statistic & {$[0.972]$} \\
Serial correlation & $\mathrm{F}(1,20)=[0.748]$ \\
& $\mathrm{F}(2,19)=[0.718]$ \\
Functional Form & $\mathrm{F}(1,20)=[0.554]$ \\
Normality & $\chi{ }^{2}(2)=[0.282]$ \\
Heteroscedasticity & $\mathrm{F}(1,25)=[0.331]$ \\
ARCH & $\mathrm{F}(1,20)=[0.738]$ & \\
& $\mathrm{F}(2,19)=[0.921]$ & \\
\hline
\end{tabular}

Notes (Table 3): Values in square brackets are p-values. In the regressor column the number in brackets next to the variable name indicates the lag length. SER is the standard error of the regression. Serial Correlation is the F version of Godfrey's (1978a, 1978b) Lagrange multiplier test of (no) residual serial correlation (see also Harvey, 1981); Functional Form is Ramsey's (1969) RESET test for (correct) functional form specification; Normality is the Bera and Jarque (1981) test for normality; Heteroscedasticity is White's (1980) test for homoscedasticity; and ARCH is Engle's (1982) test for (no) autoregressive conditional heteroscedasticity (see Pesaran and Pesaran (1997) for more details). 
Table 4: 'Bounds' test results for the existence of a long-run relationship

\begin{tabular}{l|c|c|c}
\hline $\begin{array}{l}\text { Deterministic } \\
\text { components }\end{array}$ & F statistic & $\begin{array}{c}\text { 5\% Critical Values } \\
\text { Pesaran } \text { et al (2001) }\end{array}$ & $\begin{array}{c}\text { 5\% Critical Values } \\
\text { Narayan (2005) }\end{array}$ \\
\hline $\begin{array}{l}\text { Unrestricted intercept } \\
\text { and no trend (Case III) }\end{array}$ & 12.11 & $4.94-5.73$ & $5.395-6.35$ \\
\hline $\begin{array}{l}\text { Unrestricted intercept } \\
\text { and restricted trend } \\
\text { (Case IV) }\end{array}$ & 7.71 & $4.68-5.15$ & $5.377-5.963$ \\
\hline $\begin{array}{l}\text { Unrestricted intercept } \\
\text { and unrestricted trend } \\
(\text { Case V) }\end{array}$ & 11.54 & $6.56-7.3$ & $7.36-8.265$ \\
\hline
\end{tabular}

Notes (Table 4): The specification of deterministic components refers to Cases III, IV and V in Pesaran et al (2001). The critical values reported by Pesaran et al (2001) are for large samples. Narayan (2005) has computed critical values for the 'bounds' test for small samples using the same GAUSS code used by Pesaran et al (2001). The reported Narayan (2005) critical values are based on a sample of 30 observations. The F-statistic for Case III refers to testing that $\delta=\varepsilon=0$ in equation (4). The F-statistics for Cases IV and $\mathrm{V}$ are based on a similar equation like (4) but with a trend included in the specification. The F-statistic for Case IV refers to testing that $\delta=\varepsilon=0$ and that the coefficient of the trend is also equal to zero. The F-statistic for Case V refers to testing that $\delta=\varepsilon=0$ (see Pesaran et al (2001)). 
Table 5: Results of the autoregressive distributed lag model for LRMGDP

\begin{tabular}{|c|c|c|}
\hline \multicolumn{3}{|c|}{$\begin{array}{l}\text { Dependent variable is LRMGDP } \\
\text { OLS estimation from } 1978-2004\end{array}$} \\
\hline Regressor & Coefficient & $t$-statistic \\
\hline Constant & 0.169 & 0.9 \\
\hline LRMGDP (-1) & 0.37 & 1.93 \\
\hline LRMGDP (-2) & -0.397 & -2.57 \\
\hline LRXGDP & 1.154 & 5.32 \\
\hline $\operatorname{LRXGDP}(-1)$ & -0.558 & -1.7 \\
\hline $\operatorname{LRXGDP}(-2)$ & 0.573 & 2.12 \\
\hline \multicolumn{3}{|c|}{ DIAGNOSTIC TESTS } \\
\hline Adjusted $\mathrm{R}^{2}$ & 0.6 & \\
\hline F-statistic & $\mathrm{F}(5,21)=[0.000]$ & \\
\hline SER & 0.052 & \\
\hline Durbin-Watson statistic & 2.02 & \\
\hline \multirow[t]{2}{*}{ Serial correlation } & $F(1,20)=[0.757]$ & \\
\hline & $F(2,19)=[0.906]$ & \\
\hline Functional Form & $\mathrm{F}(1,20)=[0.791]$ & \\
\hline Normality & $\chi^{2}(2)=[0.271]$ & \\
\hline Heteroscedasticity & $\mathrm{F}(1,25)=[0.169]$ & \\
\hline \multirow[t]{2}{*}{$\mathrm{ARCH}$} & $\mathrm{F}(1,20)=[0.598]$ & \\
\hline & $F(2,19)=[0.829]$ & \\
\hline
\end{tabular}

Notes (Table 5): See Notes to Table 3. 
Figure 1: Real Exports (RX) and Real Imports (RM)

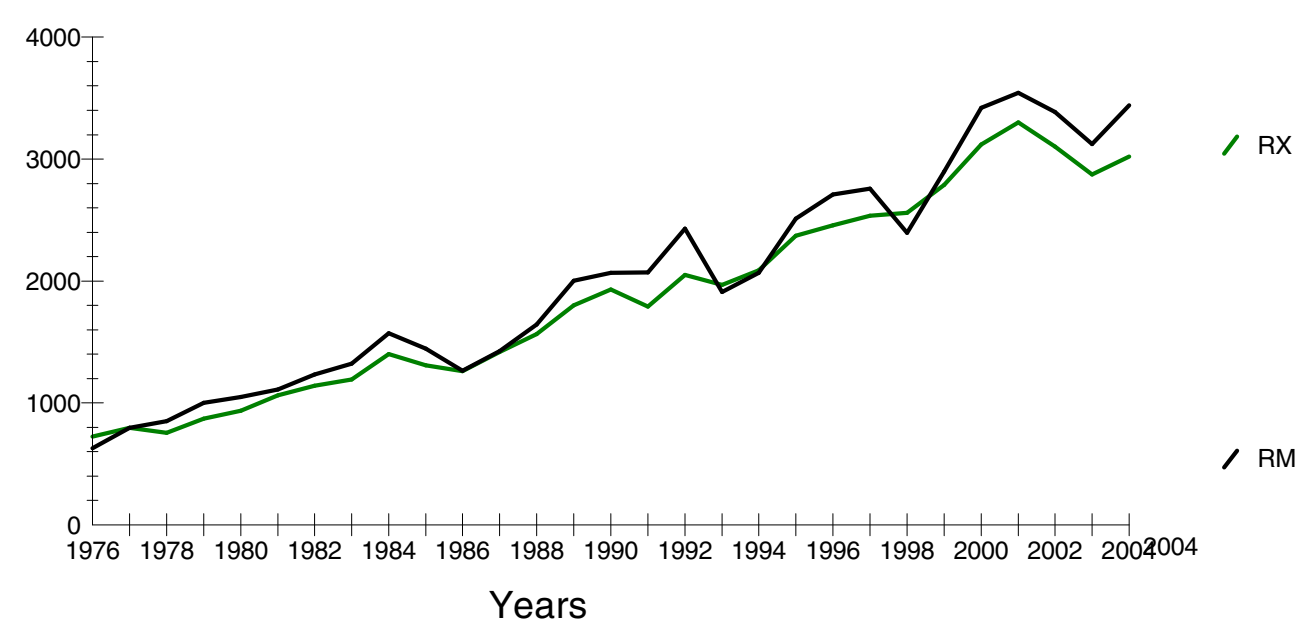

Figure 2: The Current Account Balance (RCA)

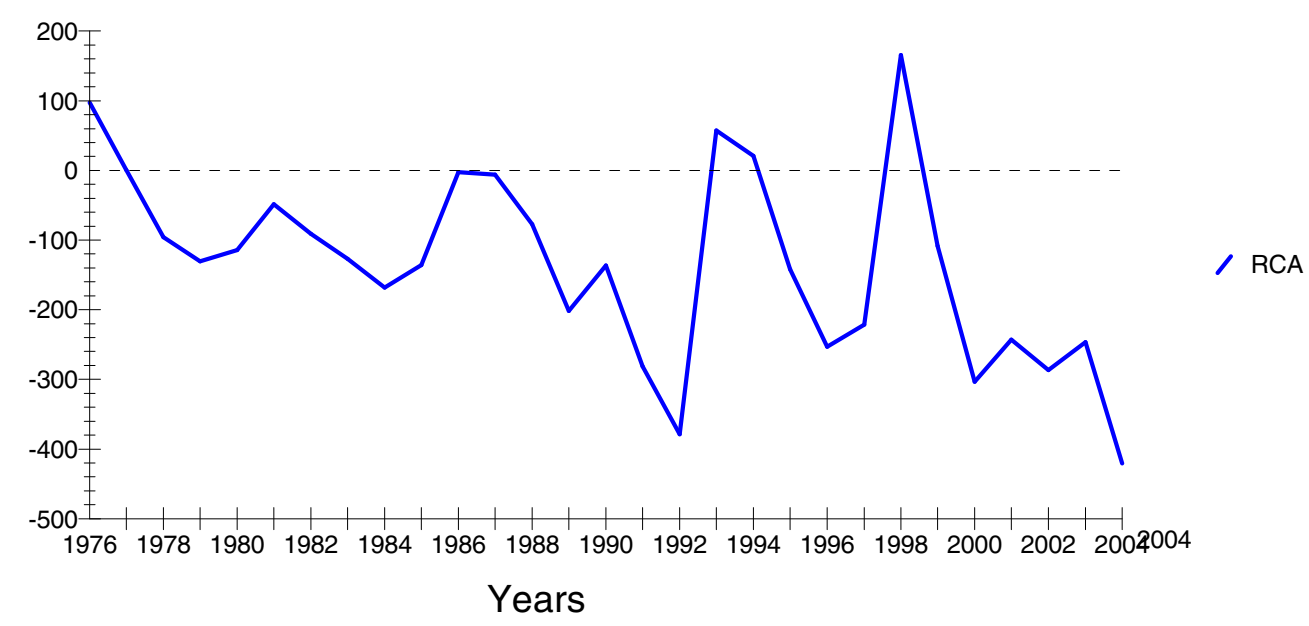

Editorial Office, Dept of Economics, Warwick University, Coventry CV4 7AL, UK 